\title{
Tables and boxes
}

\section{Tables}

0.1 Provisions for referendums and initiatives in European countries

2.1 Provisions for initiatives in Western democracies 27

2.2 State adoption of the initiative in the US 29

2.3 Turnout in November 2006 midterm elections 41

2.4 Citizens' initiated referendum results in New Zealand 45

2.5 Public perceptions of politicians and the political process 47

2.6 Should results of citizen initiated referendums be legislated by Parliament? 48

2.7 Provisions for initiatives in Germany 50

2.8 Themes in German direct democracy votes 51

3.1 Citizens' initiatives and relevant articles regulating the right to initiate legislation in the constitutions of EU member states

3.2 Signatures required for citizens' initiatives in EU member states at national level

3.3 Initiatives and treatment in the Polish Parliament (1999-2009) 68

3.4 Factors contributing to provisions for citizens' initiatives $\quad 72$

3.5 Number of eligible voters necessary to trigger a legislative initiative for each EU country $\quad 73$

4.1 Typology of revoking mandates of elected representatives $\quad 78$

4.2 California recall attempts 1913-2009 80

4.3 Successful recall attempts in California 1913-2009 (statewide offices) $\quad 80$

4.4 US States with recall provisions for assembly members $\begin{array}{ll}\text { and governors } & 81\end{array}$

4.5 Recall provisions in democratic countries 85 
6.1 Irish support for, and opposition, to the Lisbon Treaty during 2008

6.2 The result of the referendum in Ireland 2008

7.1 Electoral changes and attempted changes in independent states since 1980

7.2 Logistic regression of the propensity to hold referendums on electoral reform

7.3 Outcomes of electoral reform referendums since 1980

7.4 Average of opinion polls on the introduction of AV in the UK, 2010-11

7.5 Result of the 2011 referendum on the Alternative Vote

\section{Boxes}

1 Boris Johnson: the phone-in primary or X-Factor politics in practice

2 Condorcet's Jury Theorem: a mathematical proof of the benefits of direct democracy?

3 Direct democracy Libyan style

4 Smacking: a case study

5 Citizens' initiative on female representation in Poland, 2010

6 The Wisconsin recall, 2011: from adversarial politics to the politics of accommodation? 